\title{
Analysis of The Effect of Different Gearbox/Transmission Types on Driveline Friction Losses by Means of Gt Suite Simulation Programme
}

\author{
Mehmet Akif Kunt ${ }^{1}$ \\ 0000-0001-5710-7253
}

\author{
${ }^{1}$ Department of Motor Vehicles and Transportation Technologies, Tavsanll Vocational School, Dumlupinar University, Kutahya, 43300, \\ Turkey
}

\begin{abstract}
Selection of transmission systems of motor vehicles used on highways is highly important in terms of fuel consumption and vehicle efficiency. In this study, effect of using 3 different gearboxes in a passenger car (automatic gearbox, CVT gearbox and manual gearbox) on driveline friction losses and engine operation interval by means of GT SUITE vehicle modelling programme. The vehicle model formed has been simulated in 3 different driving cycles (WLTP, HFET and US06) and transmission system losses have been compared. In WLTP driving cycle in which speed changes and average speed are low, frictions resulting from the load constitute a significant part of total frictions; on the other hand, in driving cycles in which driving mode is aggressive and the average speed is high, frictions resulting from lubricant and sealing elements constitute a significant part of total frictions. Gearbox and related clutch mechanism selection have changed operation interval of the engine during driving cycle.
\end{abstract}

Keywords: Driving cycle, GT SUITE, transmission losses, lock-up clutches
Research Article

https://doi.org/10.30939/ijastech..945675

$\begin{array}{ll}\text { Received } & 31.05 .2021 \\ \text { Revised } & 27.07 .2021 \\ \text { Accepted } & 05.08 .2021\end{array}$

* Corresponding author

M. Akif Kunt

mehmetakif.kunt@dpu.edu.tr

Address: Department of Motor Vehiclesi Tavsanli Vocational School, Dumlupinar University, Kutahya, Turkey.

Tel:+902746148672

\section{Introduction}

Usage of driveline (clutch, gearbox, drive shaft, differential and axles) is a requirement when moving force and power need of the vehicles using internal combustion engines are analyzed. Today, driveline in automobiles using fossil fuel is designed to reduce $\mathrm{CO} 2$ emission and to provide fuel economy. Different clutch and transmission forms, attached to the same internal combustion engine, create significant emission and fuel economy changes in vehicle performance. $\mathrm{CO} 2$ emission of the vehicle can be decreased by $60 \%$ by optimizing the vehicle's chassis and driveline [1]. Gearboxes regulating the chassis of the vehicle during the cruise play an important role in driving comfort and fuel economy [2]. Usage of gearboxes in vehicles primarily started with three-speed gearboxes and has become widespread by development of four-speed gearboxes [3]. Today, field of use, desired number of speed levels, cost, comfort and performance parameters come to the forefront in selection of gearbox type.

In automotive terminology, the term "driveline" is used for a power transmission group transferring the moving force obtained from the engine into road surface, water or air [4]. The most basic gearbox technology is the manual transmission (MT). MTs provide torque and speed changes which are complying with the requirements of the vehicle by using gear groups that have different transmission ratios. Synchromesh mechanism is used in order for easy and silent coupling of the gears. Automobile manufacturers have produced automatic transmission (AT), continuously variable transmission (CVT), dual clutch transmission (DCT), automated manual transmission (AMT), and electrically variable transmission (EVT) in order to decrease exhaust emission and fuel consumption [5]. A large part of power losses occurring in AT and CVT transmission results from the torque converter used by both transmissions. Although lack of torque converter usage in MT transmissions is seen as an advantage, it is compulsory for the driver to shift gear in such transmissions at the most suitable times. 
The gearboxes controlling the clutch mechanism by means of electromagnetic or hydraulic actuators are called as automated transmission ((automated manual transmission (AMT)) [6].

In the literature, dynamic simulations have been made by using ADAMS, MapleSim and Matlab/Simulink programmes in order to reduce the cost and time loss with relation to the driveline [7]. The studies carried out have generally focused on formatting of simulations by means of making analytic models of driveline. Overall researches are related to modelling and control of MT, AT and CVT-IVT-DCT gearboxes [8-15]. In such studies, formulation methods and programme techniques related to dynamic modelling of driveline in vehicles and simulation of gearbox control have been used in general terms; transmission losses have not been examined. Numerous studies deal with total losses of both automated and manual vehicle transmissions [16-24]. An evaluation of different driving cycles on a map-based loss calculation is given in [16] and an evaluation of synchronizer losses is given in [15]. In this study, a passenger type automobile model has been formed by using GT SUITE vehicle simulation programme and gearbox losses in different driving cycles have been examined. MT, AT and CVT gearboxes have been selected.

\section{Material and Method}

In this study, model of simulation vehicle has been formed firstly. In Fig. 1, the transmission model formed by means of GT SUITE programme is shown. Such model is composed of ECU (Electronic Control Unit), TCU (Transmission Control Unit), Driver, Engine, Transmission and Vehicle elements. In the model, only transmission type has been changed and transmission losses in 3 different driving cycles have been examined. The transmission types used are automatic transmission (AT), CVT (Continuous Variable Transmission) and manual transmission (MT). While AT and CVT gearboxes use lock-up clutch, MT uses frictional dry- type single clutch. Gear ratios of the selected gearboxes are shown in Table 1.
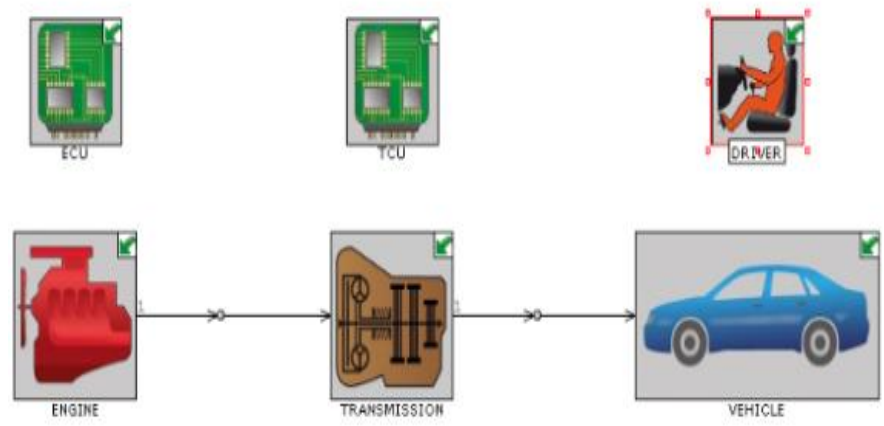

Fig. 1. GT SUITE engine transmission model

Table 1. Technical specification of transmission

\begin{tabular}{c|c|c|c}
\hline \multirow{2}{*}{} & \multicolumn{3}{|c}{ Gear Ratio } \\
\cline { 2 - 4 } & AT & CVT & MT \\
\hline 1 & 2.393 & & 2.393 \\
\hline 2 & 1.45 & & 1.875 \\
\hline 3 & 1 & & 1.45 \\
\hline 4 & 0.677 & & 1 \\
\hline 5 & & & 0.677 \\
\hline
\end{tabular}

In Fig. 2, average effective pressure (BMEP) change depending on the speed of test engine is seen. By increasing the engine speed, a throttle opening of $80-100 \%$ and BMEP of 11.14 bars at 1980$3750 \mathrm{rpm}$ interval are obtained. BMEP value decreases in all engine speed and throttle opening changes except for the stated speed and throttle opening.

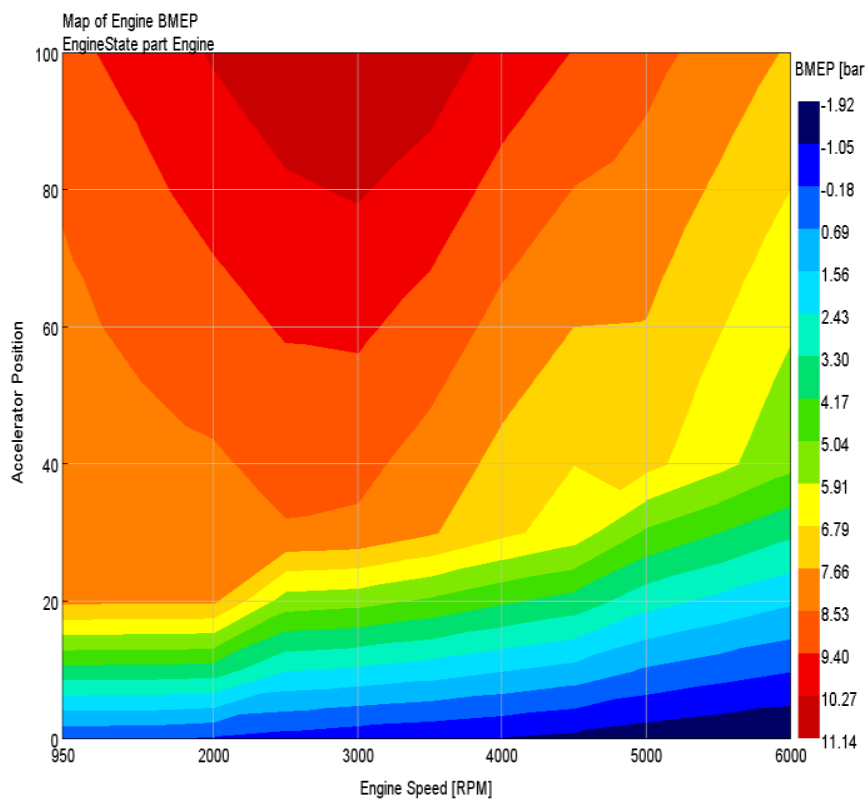

Fig. 2. Map of engine BMEP 


\subsection{Driving Cycles}

3 driving cycles widely used recently have been selected in order to evaluate inner-city, inter-city and acceleration performances of vehicles to examine clutch and transmission losses (Fig. 3).

\section{WLTP driving cycle}

WLTP (Worldwide Harmonized Light-Duty Vehicles Test Procedure) is a recent driving cycle used in approval of the sale of vehicles within European Union borders. All light-duty vehicles sold since September 2018 have been tested according to this cycle. Such cycle reflecting real driving cycle has a length of $23.24 \mathrm{~km}$ and is realised at 4 dynamic stages. Average speed in $46.5 / \mathrm{h}$, and maximum speed is $131 \mathrm{~km} / \mathrm{h}$ (Figure 3-a).

\section{HFET driving cycle}

This a chassis dynamometer driving cycle developed by EPA of USA in order to determine fuel economy of light-duty vehicles.
The cycle activates twice with an interval of maximum $17 \mathrm{sec}$.; in the first activation, conditioning of the vehicle is carried out, and in the second activation, emission is measured. The cycle lasting for $765 \mathrm{sec}$. in total has a road lenght of $16.45 \mathrm{~km}$ and its avarage speed is $77.7 \mathrm{~km} / \mathrm{h}$ (Figure 3-b).

\section{US06 driving cycle}

US06 Supplemental Federal Test Procedure (SFTP) has been developed in order to make up the deficiencies of FTP-75 test cycle in represantation of aggresive, high-speed and/or high-accelearated driving behaviour, rapid speed fluctuations and driving behaviour after start-up. The cycle has a road lenght of $12.8 \mathrm{~km}$; its avarage speed is $77.9 \mathrm{~km} / \mathrm{h}$ and its maximum speed is $129.2 \mathrm{~km} / \mathrm{h}$ (Figure 3-c).

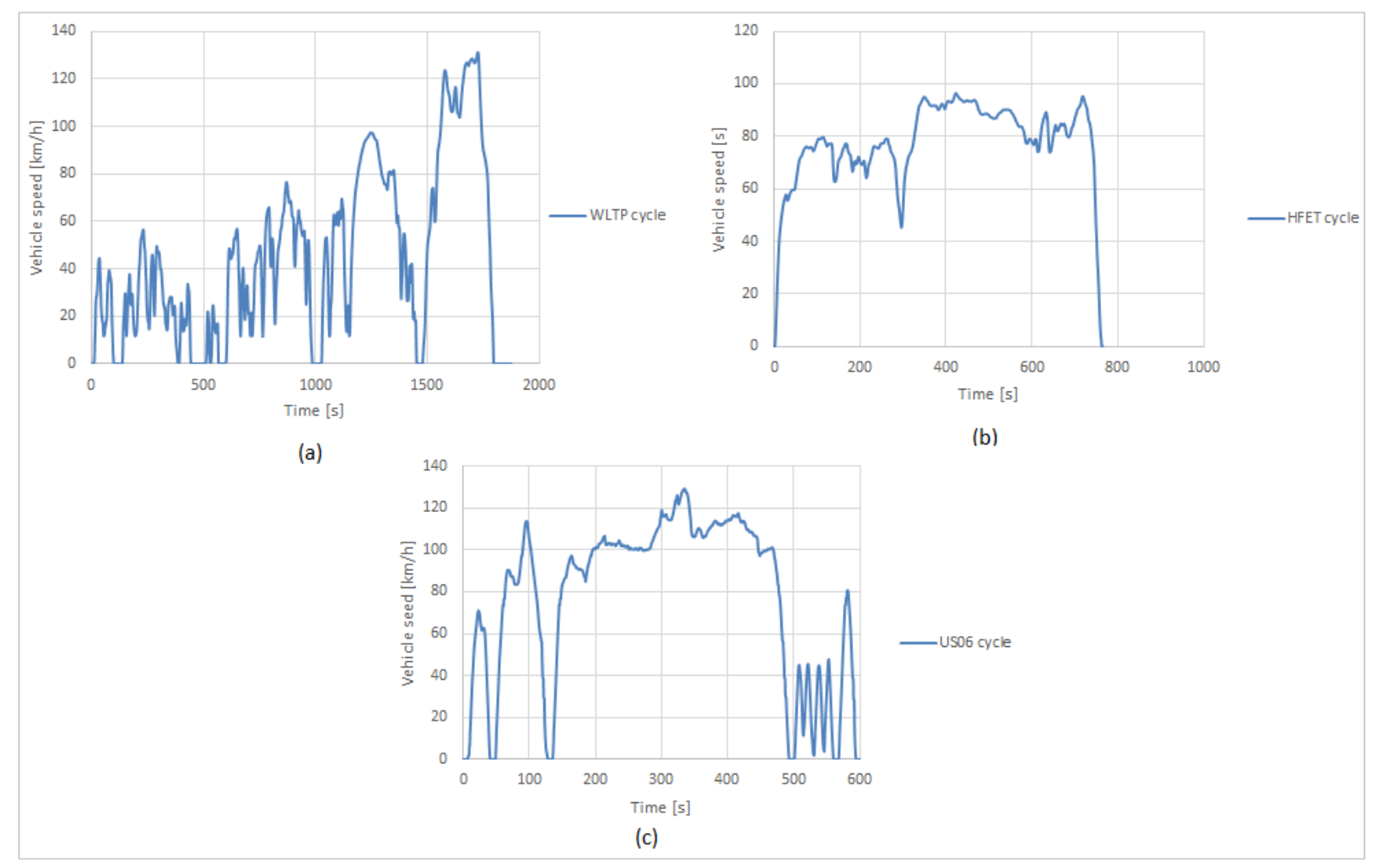

Fig. 3. Driving cycles used in simulations

\section{Findings}

In Fig. 4, BMEP change depending on engine speed has been given for driving cycle. In WLTP driving cycle, the engine using AT has functioned at $945-3200 \mathrm{rpm}$ interval, the engine using CVT has functioned 945-3800 rpm interval, and the engine using MT has functioned at 945-5000 rpm interval. Operation of the engine at larger speed range has increased friction and fuel consumption of the vehicle using MT. Transmission and the selection of clutch that can function in compliance with such transmission has operated internal combustion engine (ICE) at different speed range as per the same driving cycle. 


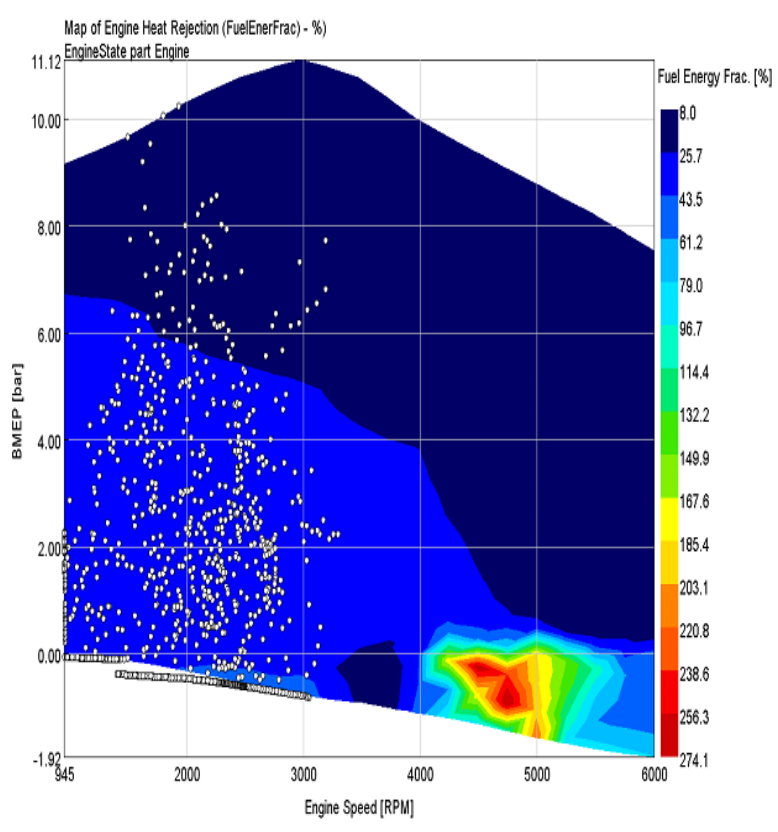

(a) AT (WLTP cycle)

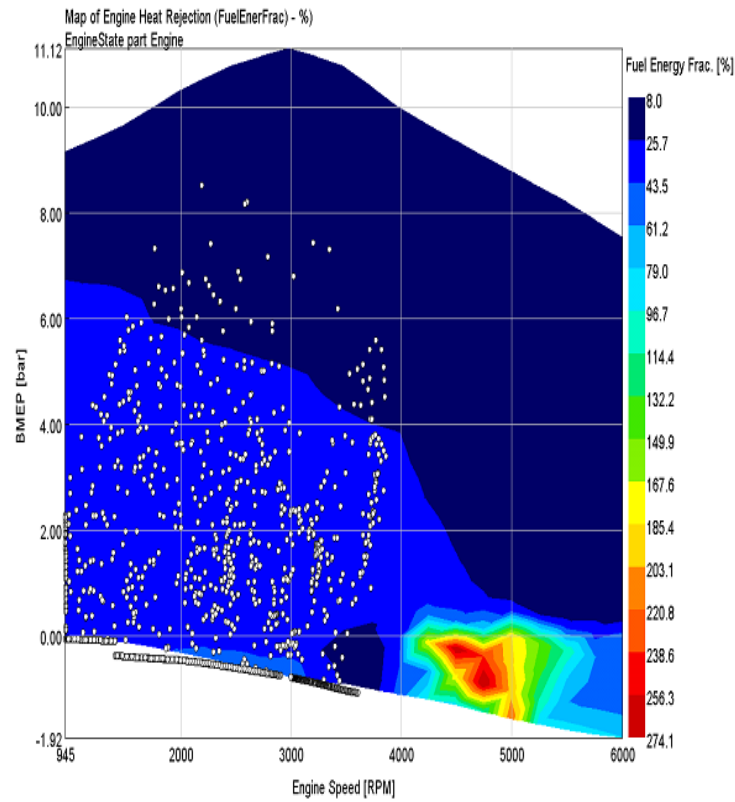

(b) CVT (WLTP cycle)

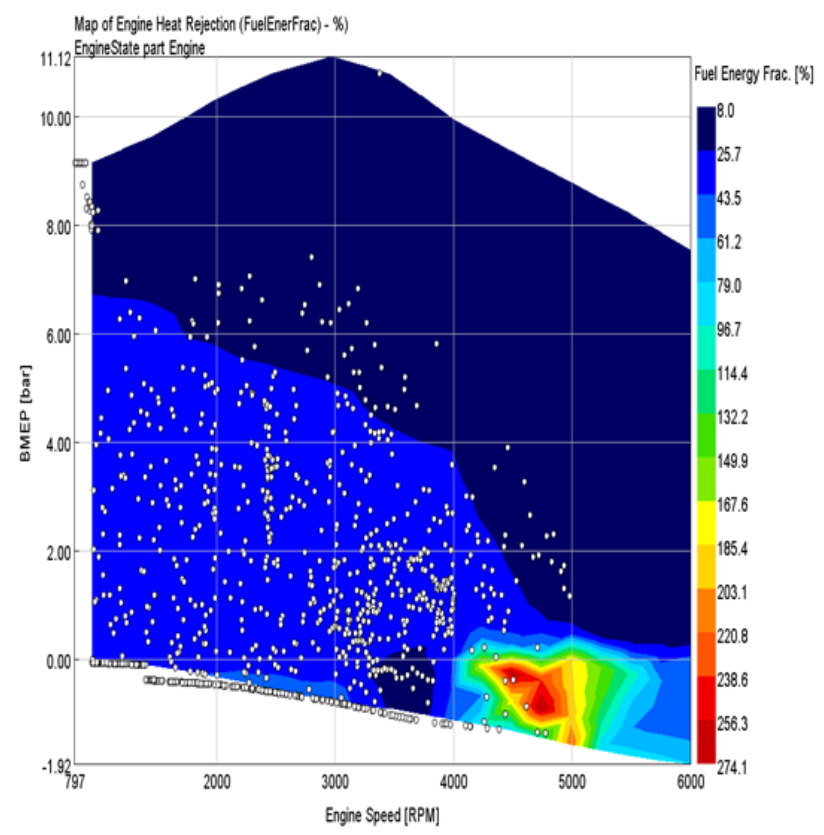

(c) MT (WLTP cycle)

Fig. 4. BMEP change depending on engine speed for WLTP driving cycle

Transmission losses are generally divided into 4 categories as gear losses, bearing (ball and roller bearing) losses, sealing element losses and other losses [14]. In Table 2, transmission losses selected according to WLTP driving cycle are given. When the losses are examined, it is seen that MT transmission losses are much more. MT transmission has 5 forward speed capacities. Therefore, in such gearbox, there has been more losses than other gearboxes, dependent on and independent from engine load. Transmission losses which are dependent on engine load are the basic determinant of the losses especially at lower vehicle speeds [15], as at lower vehicle speeds, higher speed changes and torque increases are provided when compared to higher speeds. WLTP cycle uses lower vehicle speeds compared to other cycles, and its average speed is lower than other cycles. $\mathrm{AT}$ and CVT transmissions use torque converter and a lock-up clutch in order to increase efficiency of the torque convertor. 
When such clutch is activated, converter pump and turbine parts are locked completely, accordingly power loss of the converter is reduced and it operates more efficiently [16]. Therefore, operation frequency of such clutch is of great importance for the efficiency of the torque converter. Graphic of lock-up clutch loss, obtained from GT SUITE programme, is shown in Fig. 5. According to such graphic, lock-up clutch of the torque converter of CVT transmission has operated less than AT lock-up clutch in WLTP cycle. In time interval of the cycle between 0-650 sec., lock-up clutch of CVT transmission has operated only once. It is understood that such situation results from less amount of lock-up clutch losses. For WLTP cycle, CVT lock-up clutch has caused a total power loss of $-0.12338 \mathrm{~kJ}$, and AT lock-up clutch has caused a total power loss of $-2.71047 \mathrm{~kJ}$. Although this situation is considered as an advantage for CVT transmission, such gearbox has experienced much loss in torque converter and transmission. Torque converter loss in CVT transmission has been calculated as $-1475.14 \mathrm{~kJ}$, and as $-1258.77 \mathrm{~kJ}$ in AT transmission. Moreover, when all driveline elements are taken into consideration, it is seen that driveline with CVT transmission has consumed more energy than other transmissions in WLTC cycle.

Table 2. Driveline losses according to WLTP driving cycle

\begin{tabular}{c|c|c|c}
\hline & AT & CVT & MT \\
\hline & $(\mathrm{kJ})$ & $(\mathrm{kJ})$ & -300.343 \\
\hline Clutches & -2.71047 & -0.12338 & 0 \\
\hline Torque Converter & -1259.77 & -1475.14 & -332.893 \\
\hline Transmission and Gears & -308 & -313.015 & -432.549 \\
\hline Differential, Transfer Case & -400 & -403.906 & -1065.785 \\
\hline Total & -1970 & -2192.18 & \\
\hline
\end{tabular}

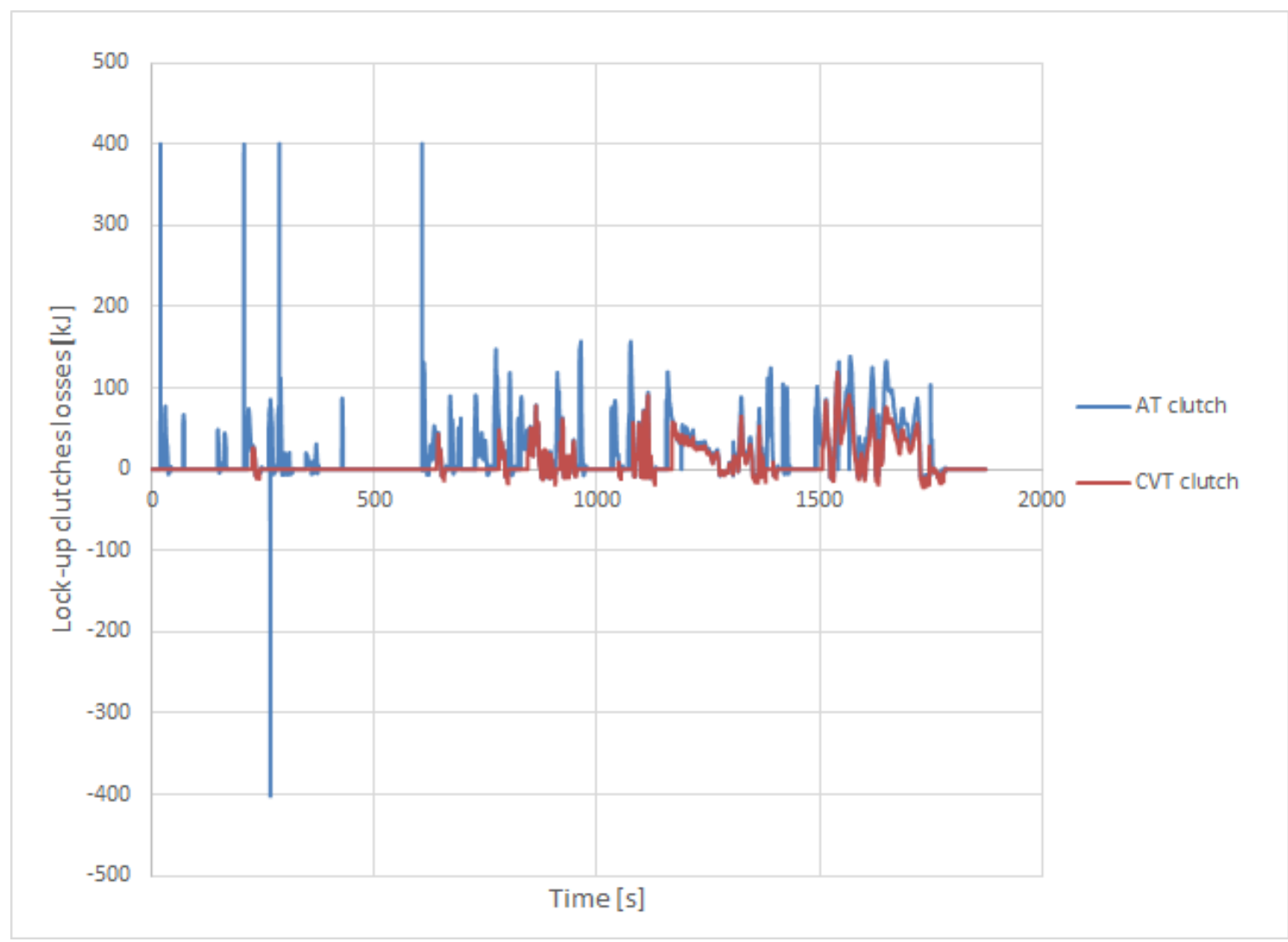

Fig. 5. Graphic of the lock-up clutch loss of transmission according to WLTP driving cycle 
gine using AT has operated at 2000-3300 rpm interval, the engine using CVT has operated at 2500-3300 rpm interval, and the engine using MT has operated at 2700-4000 rpm interval.

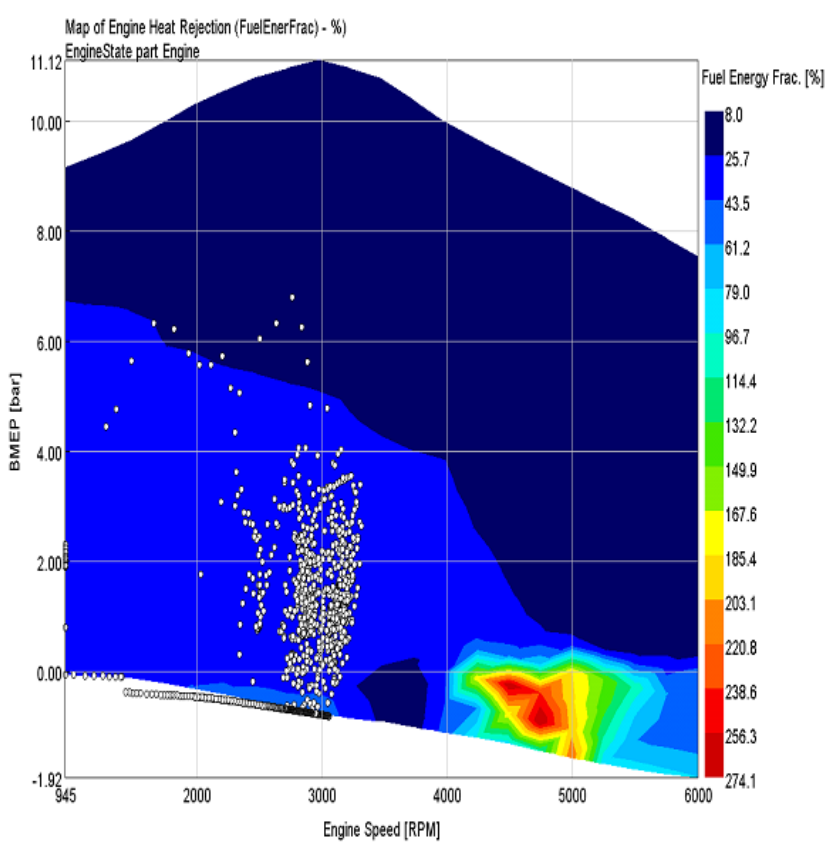

(b) CVT (HFET cycle)

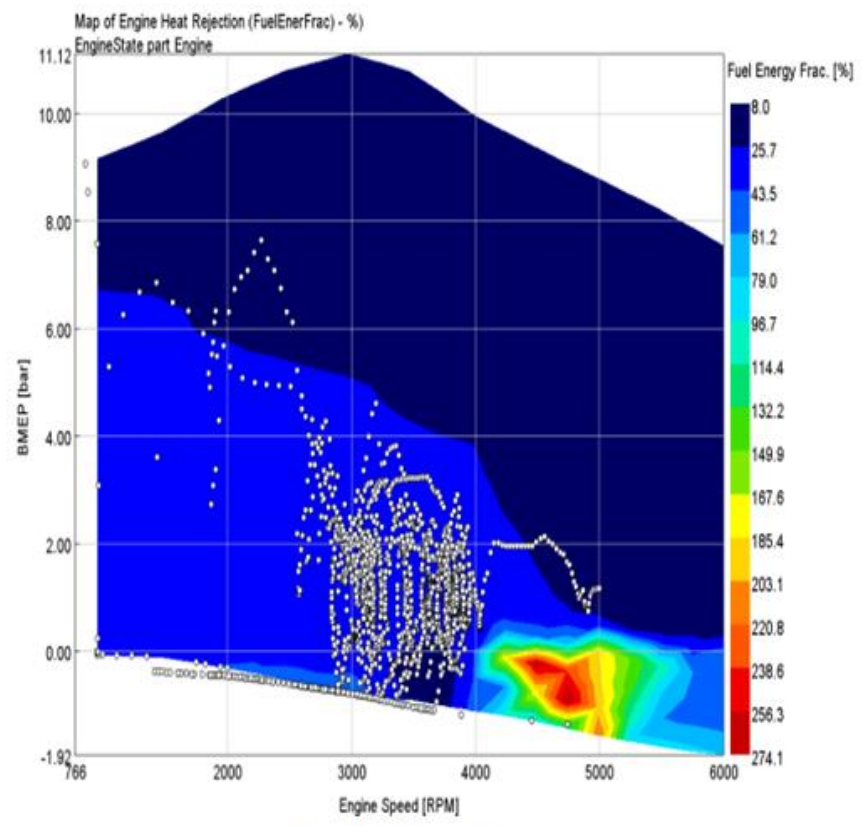

(c) MT (HFET cycle)

Fig. 6. BMEP change depending on engine speed in HFET driving cycle

In Table 3, driveline losses have been given according to HFET driving cycle. HFET cycle includes higher average speed and less speed change when compared to WLTP driving cycle. Therefore, total transmission losses are much less. As clutch mechanisms of CVT and AT are lock-up clutches, it has consumed less energy than MT clutch. The torque converter with CVT transmission has consumed $48.7 \%$ more energy compared to the torque converter with AT transmission. 
Such situation is related to frequency of lock-up usage. Increase in average speed of cruise cycle and decrease in speed changes have resulted in close figures of transmission losses. Furthermore, differential losses have decreased approximately by half compared to WLTP cycle. When all driveline elements are taken into consideration, the highest driveline loss has occurred in CVT transmission system in HFET driving cycle $(-410.385 \mathrm{~kJ})$. After such transmission system, the highest driveline loss has occurred in MT transmission system $(-392.2 \mathrm{~kJ})$.

Table 3. Driveline loss according to HFET driving cycle

\begin{tabular}{c|c|c|c}
\hline & AT & CVT & MT \\
\hline & $(\mathrm{kJ})$ & $(\mathrm{kJ})$ & -36.1776 \\
\hline Clutches & -0.286711 & -0.0618062 & 0 \\
\hline Torque Converter & -38.6852 & -56.5778 & -155.081 \\
\hline Transmission and Gears & -153.675 & -154.131 & -200.944 \\
\hline Differential, Transfer Case & -198.836 & -199.625 & -392.20 \\
\hline Total & -391.482 & -410.385 &
\end{tabular}

Graphic of the lock-up clutch loss obtained from GT SUITE programme is shown is Fig. 7. Although lock-up clutch of CVT has operated more in this cycle when compared to WLTP cycle, lock-up clutch of AT has operated more effectively in HFET cycle. Such situation is the reason of $31.62 \%$ less energy consumption of AT torque converter. Moreover, the engine to which CVT transmission is attached has operated at higher speeds. Such situation has increased torque converter losses.

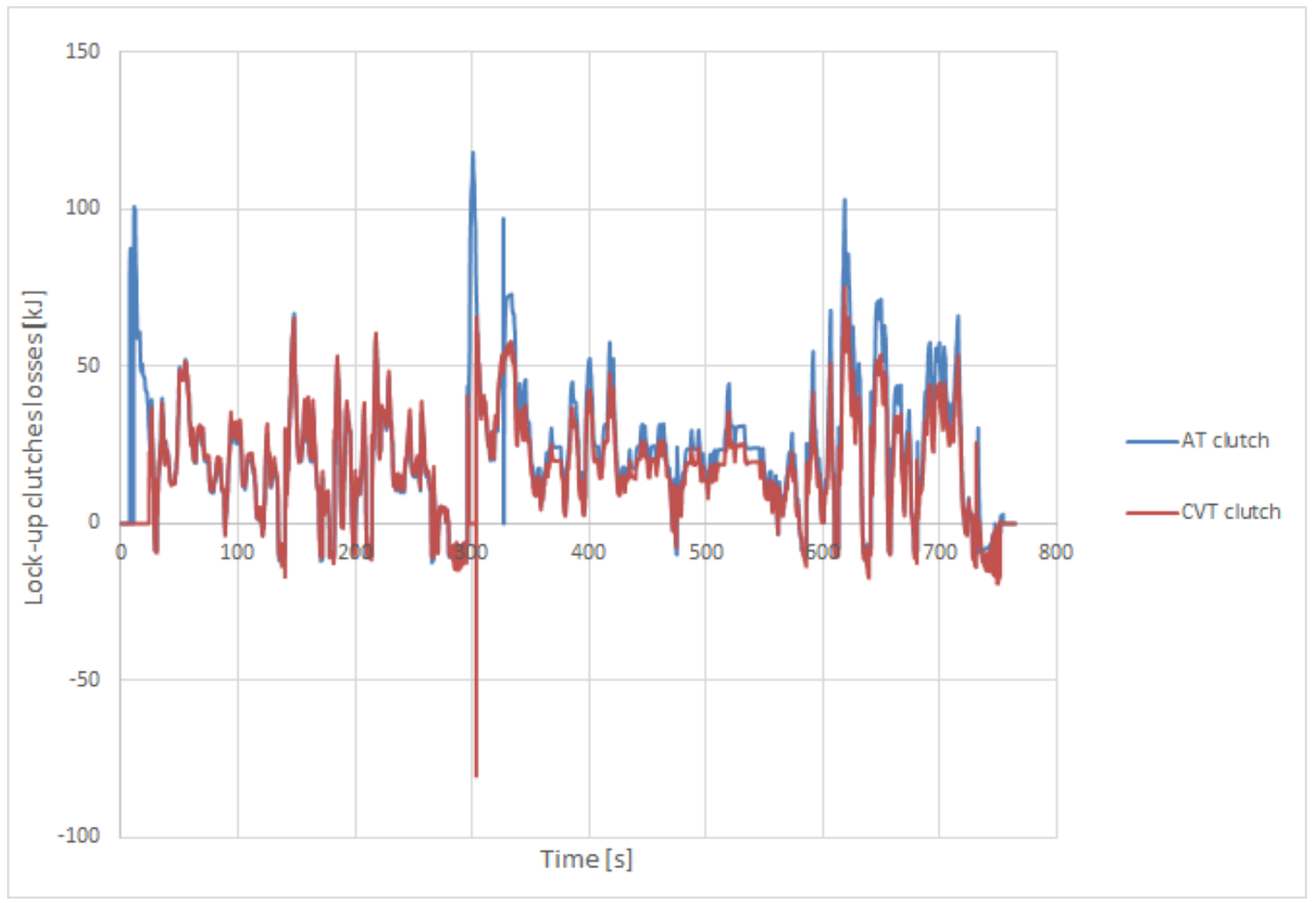

Fig. 7. Graphic of transmission lock-up clutch loss according to HFET driving cycle

In Fig. 8, BMEP change depending on engine speed has been given for US06 driving cycle. In US06 driving cycle, the engine using AT has operated at 3000-4000 rpm interval, the engine using CVT has operated at 2000-3000 rpm interval, and the engine using MT has operated at 2000-4000 rpm interval. In such driving cycle, the engine with MT transmission has operated at the widest cycle range. Internal combustion engines increases fuel consumption outside optimum operation region. 


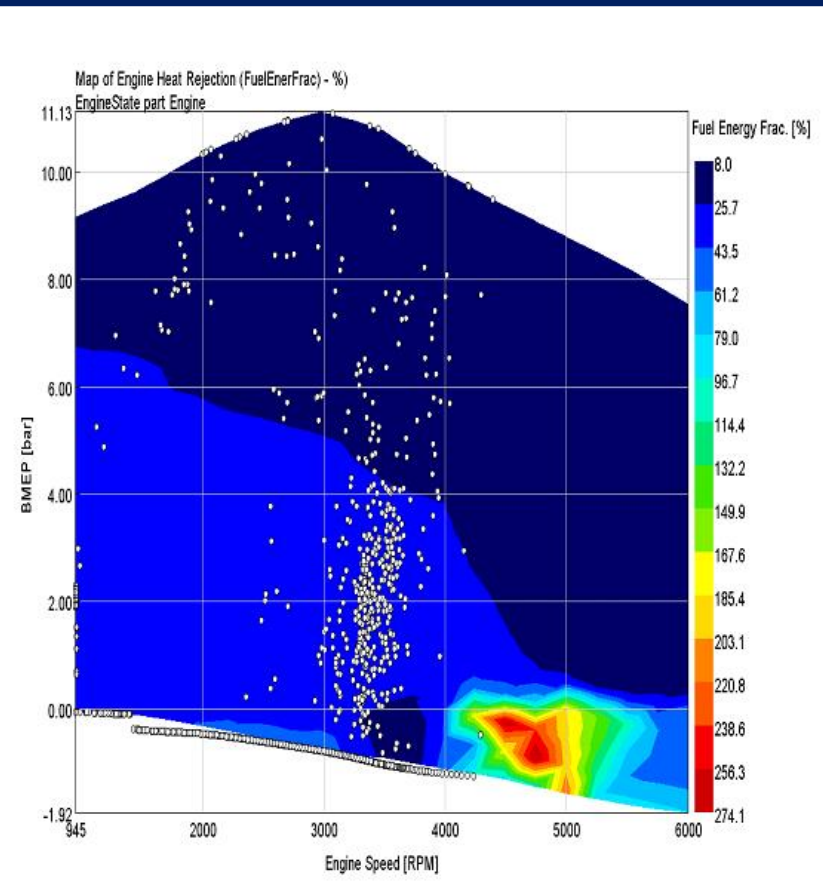

(a) AT (US06 cycle)

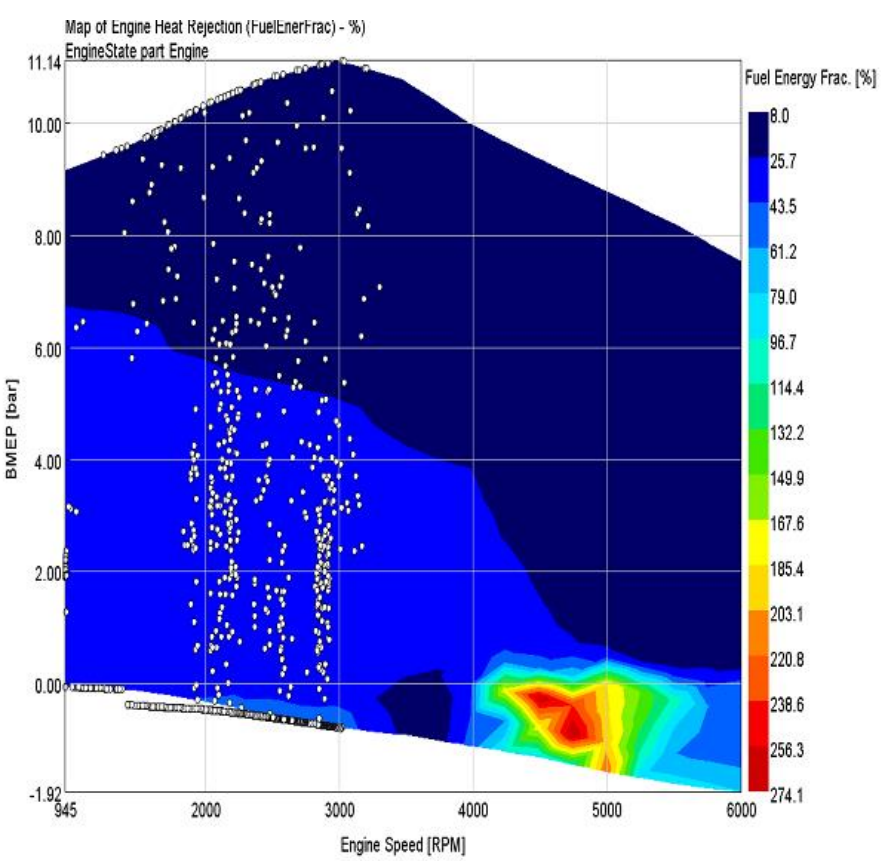

(b) CVT (USO6 cycle)

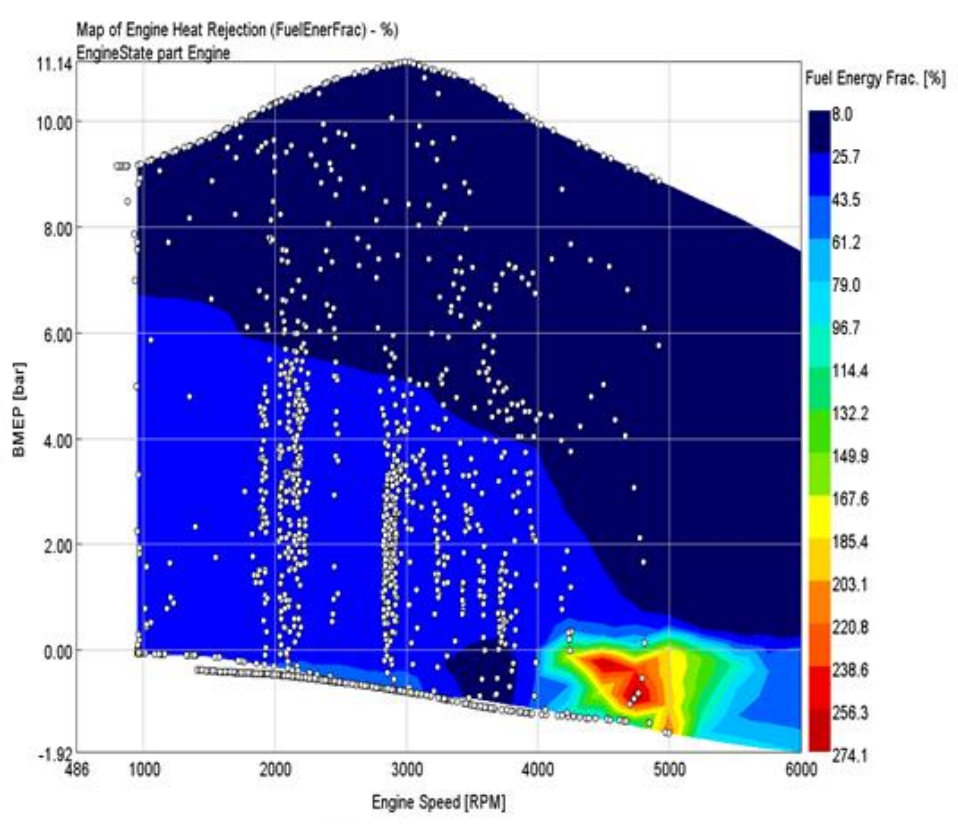

(c) MT (USO6 cycle)

Fig. 8. BMEP change depending on engine speed for US06 driving cycle

In Table 4, driveline losses have been given according to US06 driving cycle. US06 driving cycle is aggressive and has high speed and rapid speed fluctuations. Therefore, general transmission losses are higher than HFET driving cycle even though their average speeds are close to each other. The change of driving style from normal to aggressive has increases total transmission losses. Lock-up clutch of CVT transmission has not operated at 487s-579s intervals. Such situation has increased torque converter losses. Aggressive characteristic of driving cycle has increased speed-based losses in transmission and differential resulting from agitation and fluctuation of lubricant, and sealing elements. (Fig. 9) 
Table 4. Driveline losses according to US06 driving cycle

\begin{tabular}{c|c|c|c}
\hline & AT & CVT & MT \\
\hline & $(\mathrm{kJ})$ & $(\mathrm{kJ})$ & -241.988 \\
\hline Clutches & -27.3082 & -0.21871 & 0 \\
\hline Torque Converter & -293.086 & -484.318 & -211.715 \\
\hline Transmission and Gears & -208.279 & -215.073 & -275.158 \\
\hline Differential, Transfer Case & -270.379 & -277.306 & -728.86 \\
\hline Total $(\mathrm{kJ})$ & -799.05 & -976.91 & \\
\hline
\end{tabular}

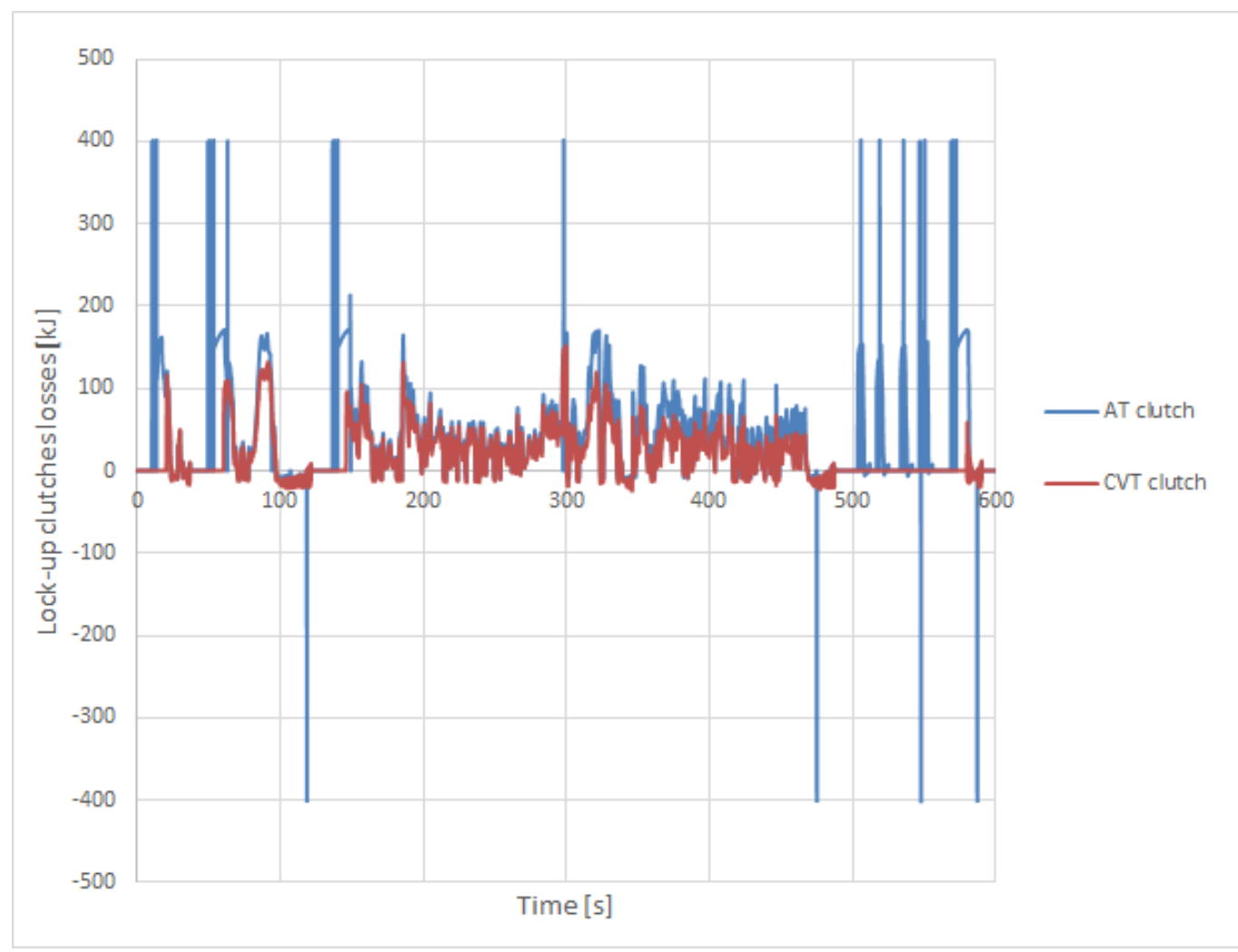

Fig. 9. Graphic of transmission lock-up clutch loss according to US06 driving cycle

\section{Conclusion}

Driving style has significant effects on fuel consumption and transmission losses in vehicles. In driving styles in which speed changes are dense and average speed is low, transmission losses depending on load increase significantly. In case of selection of aggressive driving style, agitation of lubricant and frictions resulting from sealing elements increase. Such situation is observed in transmission losses in HFET and US06 driving cycles. Selection of CVT and AT as gearboxes requires usage of torque converter and lock-up clutch.

Usage of such clutches decreases energy losses of the related gearbox. In addition, the internal combustion engines to which such gearboxes are attached provide less cycle fluctuations. This situation shall decrease engine frictions and fuel consumption as well. In all driving cycles, losses of transmission systems with AT gearbox are less than the losses of transmission systems with
CVT gearbox. The basic reasons of such situation are operational structure of gearboxes and operational frequency of lockup clutch. Although it is observed that losses of transmission systems with MT gearbox are less in all driving cycles, the engine to which such transmission system is attached has operated at the widest speed range and speed fluctuation. This shall increase engine losses and fuel consumption.

\section{Conflict of Interest Statement}

The authors declare that there is no conflict of interest.

\section{References}

[1] Paul M, 'International CTI-Symposium', Berlin, Germany, December; 2007.

[2] Aysal F. 2014. Vites Kademesindeki Artışın Taşıta Olan Etkisinin Analizi. Yüksek Lisans Tezi, Afyon Kocatepe Üniversitesi, Fen Bilimleri Enstitüsü. 
[3] Lechner G, Naunheimer H. Automotive transmissions fundamentals selection design and application. Stutgart and Augsburg: Springer; 1999.

[4] Kulkarni M, Shim T, Zhang Y. Shift dynamics and control of dualclutch transmissions. Mech. Mach. Theory. 2007; 42: 168-182.

[5] Bottiglione F, Pinto SD, Mantriota G, Sorniotti A. Energy consumption of a battery electric vehicle with infinitely variable transmission. Energies. 2014; 7: 8317-8337.

[6] Szimandl B, Németh H. Dynamic hybrid model of an electro-pneumatic clutch system. Mechatronics. 2013; 23: 21-36.

[7] Bayrakçeken H, Aysal FE. Taşıt vites kutularının simülasyon ve yol testleri ile incelenmesi. AKÜ FEMÜBİD. 2017; 17:772-780.

[8] Goetz M, Levesley MC, Corolla DA. Integrated Powertrain Control of Gearshifts on Twin Clutch Transmissions. SAE Technical Paper. 2004-01-1637.

[9] Kim D, Yang K, Hong KS, Hahn JO, Lee KI. Smooth shift control of automatic transmissions using a Robust adaptive scheme with intelligent supervision. International Journal of Vehicle Design, 2003; 32: 250-272.

[10]Zhang Y, Zou Z, Chen X, Zhang X, Tobler W. Simulation and analysis of transmission shift dynamics. International Journal of Vehicle Design. 2003; 32: 556 - 561 .

[11]Tsai LW, Schultz G, Higuchi N. A novel parallel hybridtransmission. Journal of Mechanical Design. 2001; 123: 161-168.

[12]Megli TW, Haghgooie M, Colbin DS. Shift Characteristics of A 4Speed Automatic Transmission. SAE Technical Paper. 1999-011060.

[13]Zou Z, Zhang Y, Zhang X, Tobler W. Modeling and simulation of traction drive dynamics and control. Journal of Mechanical Design. 2001; 123: 556-561.

[14]Yasuoka M, Uchida M, Katakuta S, Yoshino T. An Integrated control Algorithm for an SI Engine and CVT. SAE Technical Paper. 1999-01-0752.

[15]Butler KL, Ehsani M, Kamath P. A Matlab-based modelling and simulation package for electric and hybrid electric vehicle design. IEEE Transactions on Vehicular Technology. 1999; 48: 1770-1774.

[16]Inderwisch K. Verlustermittlung in fahrzeugantrieben. Braunschweig, Techn. Univ.,Diss, Schriftenreihedes Instituts für Fahrzeugtechnik, 2014. ISBN 978-3-8440-3274-1.

[17]Zhou X, WalkerP, Zhang N, Zhu B. Numerical and experimental investigation of drag torque in a two-speed dual clutchtransmission. Mech. Mach. Theory. 2014; 79: 46-63.

[18]Allendorf D. Getriebekonzeption auf basisvon wirkungsgradsimulationen.Techn. Hochsch. Diss. Schriftenreihe Automobiltechnik, 2018. ISBN 3946019226.

[19]Wink CH, Marson L, Goyal S. Hybrid analytical-experimental method to map power losses of automotive transmissions over their operating range. Tribol. Int. 2020; 143.

[20]Achtenova G, Pakosta J. Estimation of the Gearbox No-Load Losses, SAE Technical Paper. 'SAE 2016 World Congress and Exhibition', Apr. 2016, doi:10.4271/2016-01-1092.

[21] Yang F, Wang Y. Efficiency analysis of multi-speed automatic transmission with planetary gear trains. Forsch Ingenieurwes. 2017; 81: $163-173$.
[22]Vacca F, Pinto SD, Hartavi KA, Gruber P. On the Energy Efficiency Of Dual Clutch Transmissions and Automated Manual Transmissions.Energies.2017; 10:1562.

[23]Bianchi EL, Polinder H, Bandyopadhyay S. Energy Consumption of Electric Powertrain Architectures: a Comparative Study, in'19th European Conference on Power Electronics and Applications (EPE'17 ECCE Europe)'. 2017, pp. 1-10.

[24]Shen Y, Rinderknecht S, Hoppert M. General modellingmethod of power losses in transmission with parameter identification. Forsch Ingenieurwes. 2017; 81: 117-123.

[25] Naunheimer H, Bertsche JR, Novak W. Automotive transmissions, Springer Berlin Heidelberg; 2011.

[26] Habermehl C, Jacobs, Neumann S. A Modeling Method for Gear Transmission Efficiency in Transient Operating Conditions. Mechanism and Machine Theory. 2020;153.

[27] Mussaeus MA, Serrarens AFA, Veldpaus FE. CVT Ratio Optimization for Minimal System Losses in Passenger Cars. 